ESTUDOS GERAIS

\title{
A Dinâmica do Processo Brasileiro de Evolução Social, Política e Econômica
}

José de Almeida Rios

AS PRESSÕES E ANTAGONISMOS NO PROCESSO DE EVOLUÇÃO SOCIAL

A orgânica social e suas contradições

$\mathrm{S}_{\mathrm{x}}$ cesso naturais e necessárias as pressões e antagonismos no prode grupos mais ou menos organizados que provocam por mero mica sincrética de reajustamento sempre constante e progressiva. Eis por que, na análise dos grupos se tornam indispensáveis as identificações, as caracterizações e as definições para disciplinar, controlar, fiscalizar e dosar as ações, para que no reajustamento não seja desencadeado um processo anormal, destorcido e "perverso" frente ao sentido doutrinário da política de evolução e de desenvolvimento.

A determinante do reajustamento é positiva e pacifica, dependendo o seu desfecho favorável dos métodos de como ela se faz. Em verdade, os sistemas sociais criados para atender ao processo social de evolução e de desenvolvimento seguem linhas nais rígidas, guardando uma distância conveniente entre as reivindicações e a satisfação. E' muito natural que isto aconteça, pois que a serenidade, o senso, o equilibrio, a segurança e a técnica são atitudes e procedimentos intimamente solidários com a precaução, a previsão e a provisão sempre escassos nas cogitações de grupos interessados, coletividades e nas atitudes reivindicatórias populares.

As reivindicações populares identificam-se como pressões e antagonismos necessários ao processo de evolução social frente às fôrças sociais tradicionais. Contudo, justamente a convenção de disciplinar, coordenar, selecionar, dosar e encaminhar é que pode 
satisfazer nas condições precisas e exatas, em benefício da própria coletividade, a média de atendimentos que solidifique a harmonia e a satisfação, sem o conflito. O predominio exagerado de privilégios de grupos, ao invés de provocar uma pressão contrária conveniente, pode descambar para a violência e o conflito, sempre desfavoráveis a todos. Tal predominância, pode, inclusive, eliminar o diálogo, a polêmica, a discussão e as contradições gerando um silêncio perigoso. Êste fará suspeitar de um entrave que pode comprometer a união e a solidariedade que firmam a atitude de compromisso de todos frente ao perigo comum de destruição da própria cultura. A crítica, a discussão, a polêmica e o debate, típicos da filosofia democrática da liberdade convencional, não destroem o elo de solidariedade e compromisso de todos frente a um perigo comum. Eis por que nos conflitos as democracias podem sofrer as primeiras derrotas, mas estão sempre seguras da vitória final.

As reivindicações sociais poderiam ficar identificadas como uma pressão social especial. Contudo, para melhor argumentação didática as colocaremos nas Macropressões. Outra Macropressão. que na aparência seria passiva, tendo características conjunturais em cada grupo social, forma contudo um processo de fermentação internacional que poderia causar rupturas no equilibrio político universal. E' o impacto demográfico. A China, por exemplo, apresenta a caracteristica conjuntural de tal Macropressão que poderá implicar em uma tremenda pressão internacional. A técnica de estabelecer um processo sadio de evolução e de desenvolvimento supera as possibilidades daquela Nação. Decorre disto a sua Politica Internacional dando uma solução violenta às contendas internacionais. Transforma, assim, a sua Pressão em uma Utopia, quando julga necessário o enfraquecimento de todos para valo. rizar seu Poder Nacional. No momento tornou-se tão grave o seu problema que teve de arrefecer a sua ação de "guerra fria" para desencadear um conflito mundial. Configura-se o quadro referente àquela Nação a uma reivindicação grupal e não reivindicaçăo popular. Sòmente os esforços conjugados de tôdas as nações poderão corrigir a situação demográfica da China Continental, aumentando progressivamente em gravidade. Tal Pressão colocada no plano universal pode afetar particularmente nosso país, com suas imensas áreas despovoadas. Quando se apresentar a solıção em têrmos universais, poderemos não ter ocupado ainda nossos imensos "espaços vazios". O panorama politico internacional ainda se apresenta indeciso, colocando nos de sobreaviso acêrca dos rumos a serem tomados frente a uma solução média harmoniosa que reajuste a tensâo universai. Dois grandes 
campos econômicos disputam a preeminência Politica visando manter e expandir as próprias economias. Um, do ocidente, reformulando sua filosofia democrática de vida e fazendo-a ultrapassar as fronteiras geográficas, com insistente solicitação à ideologia, antepóe-se a outro que joga com um sentido místico de uma pretensa ideologia que diz seguir, procurando, pela propaganda, impingi-la como Utopia salvadora para naçóes em fase retardada de desenvolvimento. Uma terceira fôrça encara como desfavorável a suas aspirações e interêsses a disputa entre dois campos, procurando situar-se como potência atômica e dispor da nova fonte energética de paz e de guerra. E' a França. Realmente encontra-se o mundo na alternativa de duas fôrças sconômicas dificultando fora delas maior flexibilidade de ação para satisfazer reivindicações de mercados e matérias-primas. Sob o ponto-de-vista ideológico, dentro da dinâmica politica internacional, a posição de nosso país não pode sofrer de hesitação. Mesmo em se considerando uma alternativa, todos os fatôres materiais e morais nos colocam na esfera da filosofia democrática de vida que tem como fundamento a liberdade de idéias e de pensamentos, a convenção restritiva de maioria como caminho estabelecido na lei emanada do povo.

Como estamos no século da quebra das doutrinas e das tradições, topamos com uma Utopia que prega exatamente uma sujeição totalitária do gênero humano, como fórmula de reivindicação profissional. Acena, pois, com a destruição da maior conquista popular, que foi conseguida pelos maiores sacrificios e que demorou milênios. Foram os grupos profissionais organizados, a partir do início da industrialização, em fins do século XVIII, que serviram de pontas-de-lança das reivindicações populares. Agora, porém, tal Utopia contraditória e falsa colocou-se a serviço de uma nação que aspira multiplicar por dez vêzes seu Poder Nacional para equiparar-se a um grupo ideológico que dispõe da Tecnologia. À guisa de propaganda pretendem com tal dispositivo político solucionar os complexos problemas do subdesenvolvimento, em pleno apogeu da Tecnologia e do Planejamento. No que nos diz respeito o plano luta para obstruir o potencial natural insuficien temente aproveitado e a presença de uma possante massa consumidora em fase de crescente expansão. A utilização da Tecnologia e do Planejamento em tal conjuntura enfraqueceria sobremodo aquela política, comprometendo as suas aspirações. Dentro de nosso pais existe uma minoria que equivocamente trabalha por elas, mesmo se contrapondo aos nossos próprios objetivos nacionais. Não é demais lembrar que as revoluçöes nunca atenderam as reivindicaçóes populares e sempre propiciaram a mudança de mãos dos privilégios sociais. 
ENSAIO DE CLASSIFICAÇÃO DAS PRESSÕES E ANTAGONISMOS

\section{A Identificação e a Caracterização}

Com o avanço técnico das comunicações caminha o mundo para sua unidade cultural partindo da ginástica do pensamento e pelas idéias inovadoras e reformadoras. Assim, cada vez mais vãose ampliando os interêsses e aspirações, agrupando sociedades variadas e heterogêneas. Quanto mais se integra no processo de civilização, mais se tornam complexos, diversificados e agigantados os problemas pessoais, tornando-se o individuo cada vez mais sujeito a restrições e coações ligadas ao interêsse comum. O mesmo fato é constatado no que se refere a assuntos e problemas nacio nais, sempre mais entrosados dentro da dinâmica das idéias e pensamentos universais. Eis por que é difícil definir com segu rança quando uma pressão ou antagonismo tem ou não raizes no campo politico universal. Por outro lado, as características con junturais nem sempre afinam sincrônicamente pela telecritica que se possa arriscar dos processos, métodos e técnica das pressões na esfera estrutural. Na apreciação qualitativa e quantitativa das pressões e antagonismos deveremos ter sempre em mente a determinação de um reajustamento estrutural tendendo a corrigir dis torções do aspecto conjuntural. Pela análise e pela critica é preciso ressaltar as duas caracterizações, evidentemente sujeitas a se plasmarem por condições especificas históricas, de evolução politica e de tradições. Por outro lado, em condições especiais de evolução e de desenvolvimento, certas pressões podem passar por várias graduações conforme as modificações que se façam sentir na conjuntura, julgando-as em sua atuação, favorável, natural, desfavorável e mesmo nefasta desde que apreciada em fases diferentes de confronto com a dinâmica social em julgamento. No momento presente quando se observa uma violenta modificação social, torna-se difícil atender dogmàticamente a determinações
doutrinárias em tôda a sua plenitude.

As fisionomias das pressões variam conforme encontram oposições ou dificuldades, assumindo caracteristicas politicas em concomitância e em transfiguração de ação econômica, adquirindo, outrossim, simbiose com as formas ideológicas, utópicas e muitas
vêzes revolucionárias.

Vimos, assim, as dificuldades da identificação, das caracterizações, dos intuitos ocultos pelas místicas, ideologias e utopias. Em um esfôrço de disciplinação daremos a seguir o quadro que
estabelece um ensaio de identificação dos grupos de presșão. 
IDENTIFICAÇÃO DAS PRESSÕES E ANTAGONISMOS QUE POSSAM AFETAR A CONSECUÇÃO DOS OBJETIVOS NACIONAIS

Classificação:

a) Internacionais

b) Nacionais

c) Mistos

Caracterização:
a) Estruturais
b) Conjunturais

Forma:
a) Ideológicos
b) Utópicos
c) Revolucionários.

Análise e critica:
a) Favoráveis
b) Naturais
c) Desfavoráveis
d) Nefastos

\section{UM EXEMPLO}

\section{NACIONALISMO}

O Nacionalismo é uma pressão nacional, estrutural, ideológica e favorável
NACIONALISMO EXTROVERTIDO

O Nacionalismo extrovertido, politico-partidário, inadequado, inoportuno e vulga:izado é: misto, conjuntural, revolucionário e desfavorável

\section{AS PRESSÕES SOCIAIS E SUAS ORIGENS}

A Politica das pressões e os sistemas sociais

As pressões sociais assumiram sempre o caráter politico desde que foi conseguida a diversificação dos sistemas monopolizados pelo "pater-famílias" na idade antiga. Estas pressões visavam à individualização dos sistemas sempre orientados para atender aspirações, interêsses e necessidades dos povos. Como as "pressões" que identificavam as atitudes, as ações e as manifestações decorrentes dos objetivos perseguidos, tomavam através dos tempos formas e características adequadas, iam assumindo novas fisionomias à medida que progredia o processo de evolução e de desen- 
volvimento. Contudo, os sistemas tendem sempre para o equilibrio e para a "prudência" com que regulam as satisfaçǒes. Com tal aspecto dão um sentido de retardo frente às evoluções sociais, provocando continua e perene solicitação para manter a linha natural de progresso. Funciona assim um mecanismo antagônico natural onde os sistemas fazem sempre o papel coercitivo conven cional procurando equilibrar interêsses, aspirações e necessidades frente à ambição dos grupos. Têm, pois as pressões sociais efeitos favoráveis e desfavoráveis conforme sejam aquelas necessida des, interêsses e aspirações identificados com cada grupo social. Quando êste adquire um sentido amplo e uniforme, passa a constituir c cbjetivo da nacionalidade. Eis por que poderemos descobrir pressões e antaganismos particulares, parciais e nacionais. Por outro lado, certas pressões atuando em ocasiões e oportunidades especificas podem ser ou não favoráveis aos interêsses da nacionalidade, lançando mão, algumas vêzes, de processos disfarçados ou obscuros para atender a um segmento social em detrimento do grupo social. Os antagonismos dentro da imensa capa cidade moderna da técnica de comunicações e de difusão poilem tomar proporções desmedidas visando atingir a "opinião pública", e, mesmo, alterar o padrão de caráter nacional. Assim, um dos sistemas - o Estado, pelo seu mecanismo de ação, o govêrno, -- precisa dispor êle mesmo das fontes reais e cientificas de pesquisas. O campo do antagonismo atingiu e agigantou-se na esfera internacional levando as nacionalidades, em defesa de suas prer rogativas de cultura, a estabelecerem "técnicas e táticas" de pro paganda política, defendendo sempre "ideologias e utopias" que satisfaçam aparentemente aquelas aspirações, interêsses e necessi-
dades das diversas nacionalidades. Uns procuram servir-se da
filosofia democrática que foi razoà filosofia democrática que foi razoàvelmente cumprida quanto $a$ seus prôprios interêsses e aspirações nacionais, mas falseadas quanto ao procedimento com outras nacionalidades. Outros ser vem-se uma "utopia" ou doutrina que nunca procuraram seguir, de ser satisfeita a uma grande parte da humanidade ainda na fase lentos de reivindicacoóes. necessidades, sujeita pois a surtos viopolitica internacional se ela estivesse valor tais manobras de culturai apropriada e mais bema estivesse de posse da consciência nais. O campo social se apresentanhoada dos preceitos educacioveis para receptividade, comprometend com requisitos favorápara satisfação do grupo social astendo o sucesso dos esforços conseguirem "uniformizar" " Enquanto, porém, não logo", o diálogo, a polêmica fôrça e transformar em "monóvisando ao bem coletivo, estarão arriscadoa e a conclusão média e tornados marginais ao prorão arriscados a serem desmascaradıs pois, de grande importância a identificação e o oportunismo de 
tais pressões para conseguir-se a definição favorável ao bem coletivo. Para isto, necessitamos fazer uma análise perfunctória da evolução social e das fôrças disciplinadoras que procuram racionalizar as pressões e os antagonismos com que se defrontará a nacionalidade para perseguir suas aspirações, atingir seus objetivcs e atender a suas necessidades.

\section{Algumas consideraçôes sôbre a evolução sócio-econômica do Pais}

Dentro do quadro universal da evolução politica, representa , Brasil um aspecto nitidamente pioneiro no que respeita a conceituar uma Organização Institucional de progresso, de evolução e de desenvolvimento. Contraria na sua dinâmica social aspéctos doutrinários seguidos por países já satisfatòriamente desenvolvidos. Desde o descobrimento, começou a ser prêsa de espoliação e de uma forma tipicamente colonial de trabalho, quando figurava aspectos da pré-história da exploração do trabalho escravo. Já então se esboçava a "dualidade cultural" tão bem focalizada por Jacques Lambert, quatro e meio séculos após. $\mathrm{Na}$ ocasião, as relaçōes culturais e econômicas na esfera internacional se faziam com uma sociedade em pleno período feudal. As riquezas daqui retiradas serviam apenas para manter a vida dos nobres privilegiados da Europa, especialmente a civilização aventureira do Mediterrâneo. Começou nosso país a participar intensamente da "revolução comercial" muito reativada e comprovada mais tarde. Muito contribuiu isso para formação em Portugal de uma classe burguesa bem mais cedo do que nos demais países europeus. Não havia qualquer sentido de formação social, nem aquisições culturais, nem tinha sentido a educação popular. Na época de estreitos interêsses do clero na vida material, sòmente se encontrava alguma erudição livresca e sujeita a dogmas religiosos, nos meios dominados pelo clero católico romano, intimamente entrosado com a classe dominante, nas côrtes de Espanha e Portugal. No século XVI, em foco, começou uma revolta, na França, mesmo entre elementos do clero católico, contra os desmandos e "privilégios materiais do clero". Foi justamente quando se iniciou a ampla reação que se seguiria na Alemanha com Lutero, na Suiça, com Calvino e a separação da igreja inglêsa. Foi o período da Reforma. Nas colônias o processo não demonstrava ainda sinais de qualquer modificação. Com tais prerrogativas servia o púlpito no Brasil para fazer política visando aos interêsses do grupo religioso. Não havia delineada qualquer idéia de interêsse público. Predominava o grupo econômico para aumentar seu poder e ampliar o campo de seus privilégios. A pressão político-religiosa visava apenas à exploração e, com o envio de riquezas, agradar 
a ambição de luxo das côrtes. Com a exploração do ouro e preciosidades naturais, exacerbou-se a luta dos grupos para disputar os privilégios e as graças reais. A cupidez exagerada neste sentido despertou a reação contrária que propugnava por melhor tratamento para aquêles que extraíam as riquezas com ajuda do trabaiho escravo. Formava-se uma classe burguesa no País, e, com ela, os primeiros rumôres de rebeldia. Como existiam poucos letrados que assumiam posições salientes na sociedade, passou a despertar maior interêsse, na burguesia nascente, a educação dos filhus varões. Por outro lado, parte do clero desprotegido também assumia atitudes rebeldes, tal como na Europa. Havia padres maçons, políticos, poetas etc. O mesmo púlpito, que servia aos intermediários e potentados das côrtes, passou a ser instrumento da "nascente burguesia", como um grupo de pressão mais organizado visando a retirar os privilégios então reinantes. A Inconfidência Mineira foi uma conjuração de padres e poetas. Ficou caracterizado o primeiro grupo de pressão política, organizado, atuando como semente da futura independência política formal. O movimento começou a criar substância quando se deslocou a formação dos bacharéis de Coimbra para Olinda e Recife.

A criação das Capitanias foi uma tentativa de fortalecimento e riqueza. Ao mesmo tempo serviria para amparar melhor os interêsses da Metrópole contra as nações estrangeiras que viam e previam o futuro promissor do Nôvo Mundo. Portugal e Espa. nha não tinham contudo pendores para produção $e$ industrialização e, sim, pelo comércio, que haviam herdado dos fenícios. Como, porém, tôda a politica portuguêsa era inteiramente dependente da inglêsa, descurava-se, também pela fôrça dos convênios e tratados, da técnica de produção. A burguesia brasileira era, por sua vez, dependente da Metrópole. Eis por que tôdas as trans. formações políticas brasileiras se seguiram sem qualquer mudança sensivel na estrutura social. A falta de preparação educacional e a intensa transmissão cultural impregnavam nas elites e nos homens de govêrno um profundo senso de alienação, que persistiria até as três primeiras décadas do século XX. A falta de consciência dos problemas nacionais e deficiente capacidade de adaptação da cultura européia de nossas elites ao campo especifico do
processo de evolução que nos atingia, causou males que chegaram
até nossos dias. A pior alienação de até nossos dias. A pior alienação de que fomos vítimas foi no que se refere à educação escolar. Nunca ocorreu ao homem de elite no Brasil a pergunta - com que finalidades educar o homem brasileiro? Havia um Brasil de Senhores que agiam e pensavam conforme a cultura européia e o Brasil que produzia, escondido, 
retraido, humilhado e envergonhado. O complexo de colônia perdurou até os fins do século XIX.

Assim, pois, desde que foi encontrada a terra de Santa Cruz, a intenção era dilatar o Reino, anexando novos domínios ao Império de Portugal. Não se tratava de plantar uma semente de pais autônomo, preparando uma estrutura política e administrativa adequada. O propósito era predatório, explorador e sugador. Desde os governadores das capitanias até os vice-reinados, o objetivo era explorar sempre e perenemente como colônia a nova terra descoberta. A pressão politica decorrente de tal idéia produziu efeito até nossos dias. Isto, aliás, se pode compreender dado que foi sòmente a partir da era industrial, iniciada no século XVIII, que começou a haver certa configuração social brasileira provocada pelas necessidades de matérias-primas determinadas pelo nôvo ciclo econômico que se instalava. O passo importante, que não pode deixar de ser assinalado, foi a abertura dos portos, em 1808, com a vinda de D. João VI para o Brasil. Naturalmente, continuaram as pressões contrárias ao desenvolvimento do País, dado que a Inglaterra conseguia privilégios na exportação de seus produtos manufaturados, firmados formalmente pelo tratado de Methuen em 1703. Pressionado pela Inglaterra, D. João VI voltou para Portugal em 1821. Se aqui permanecesse, talvez hoje formássemos um Império Brasileiro-Português, correndo o risco de fragmentação territorial, pela desintegração do prestígio político da Metrópole.

A nossa independência levada a efeito por um principe português pouco veio modificar a estrutura social do País. O mesmo aconteceria com a proclamação da República. Continuava a dominar o País um forte domínio feudal. Contudo, quatro acontecimentos internacionais influiram sobremodo para modificar a es. trutura social brasileira, alterando o padrão do caráter nacional: a queda da França em 1870, as duas últimas guerras mundiais de 1914 e 1940, e a crise econômica norte-americana de 1929. Os quatro acontecimentos concorreram para a industrialização brasileira que configurou um grupo profissional que proporcionou melhores perspectivas de satisfação das reivindicações populares. Outras Micropressões se estabeleceram no aspecto conjuntural levando a que atuasse a Macropressão das reivindicações populares caracterizando a mudança de estrutura social. O Estado teve de tomar parte na nova estrutura social e ampliou a buro- 
PRESSÕES LEGITIMAS SŌBRE A ADMINISTRAÇÃO PÚBLICA

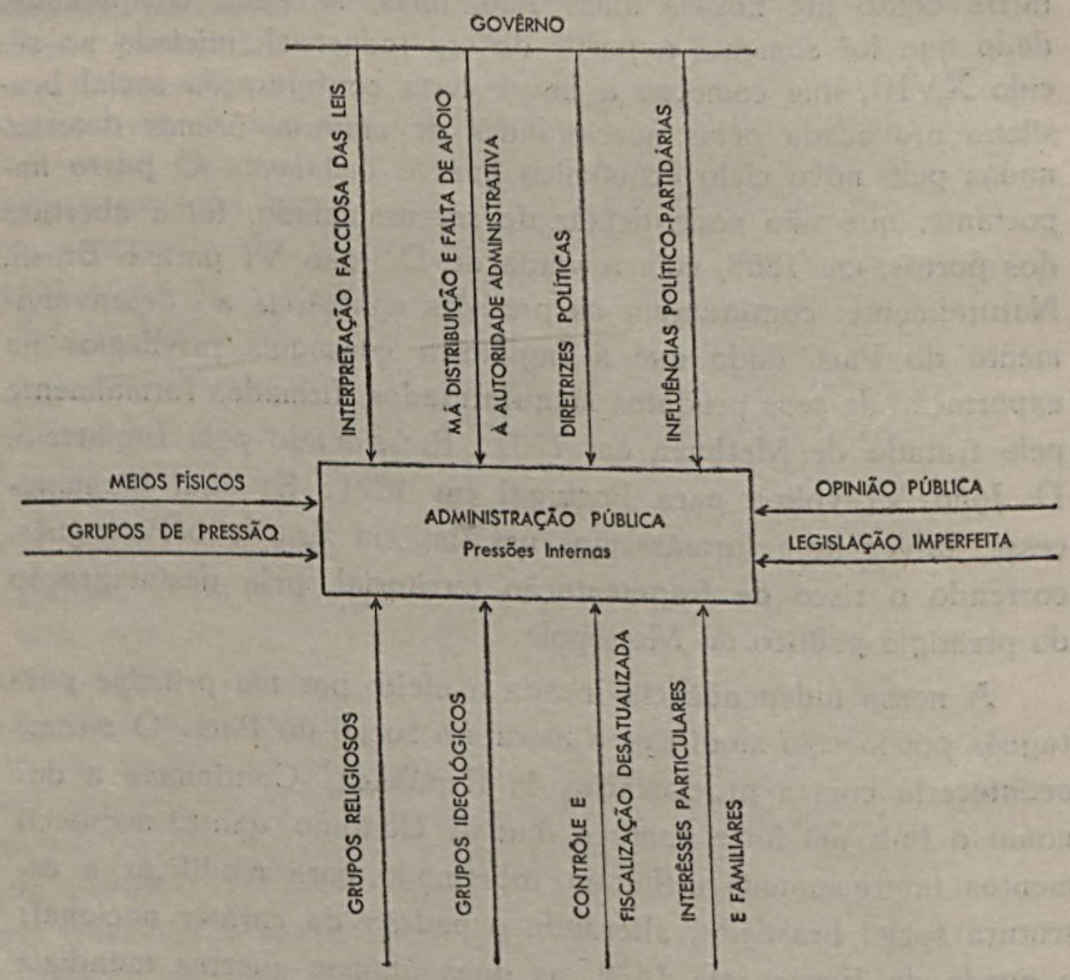




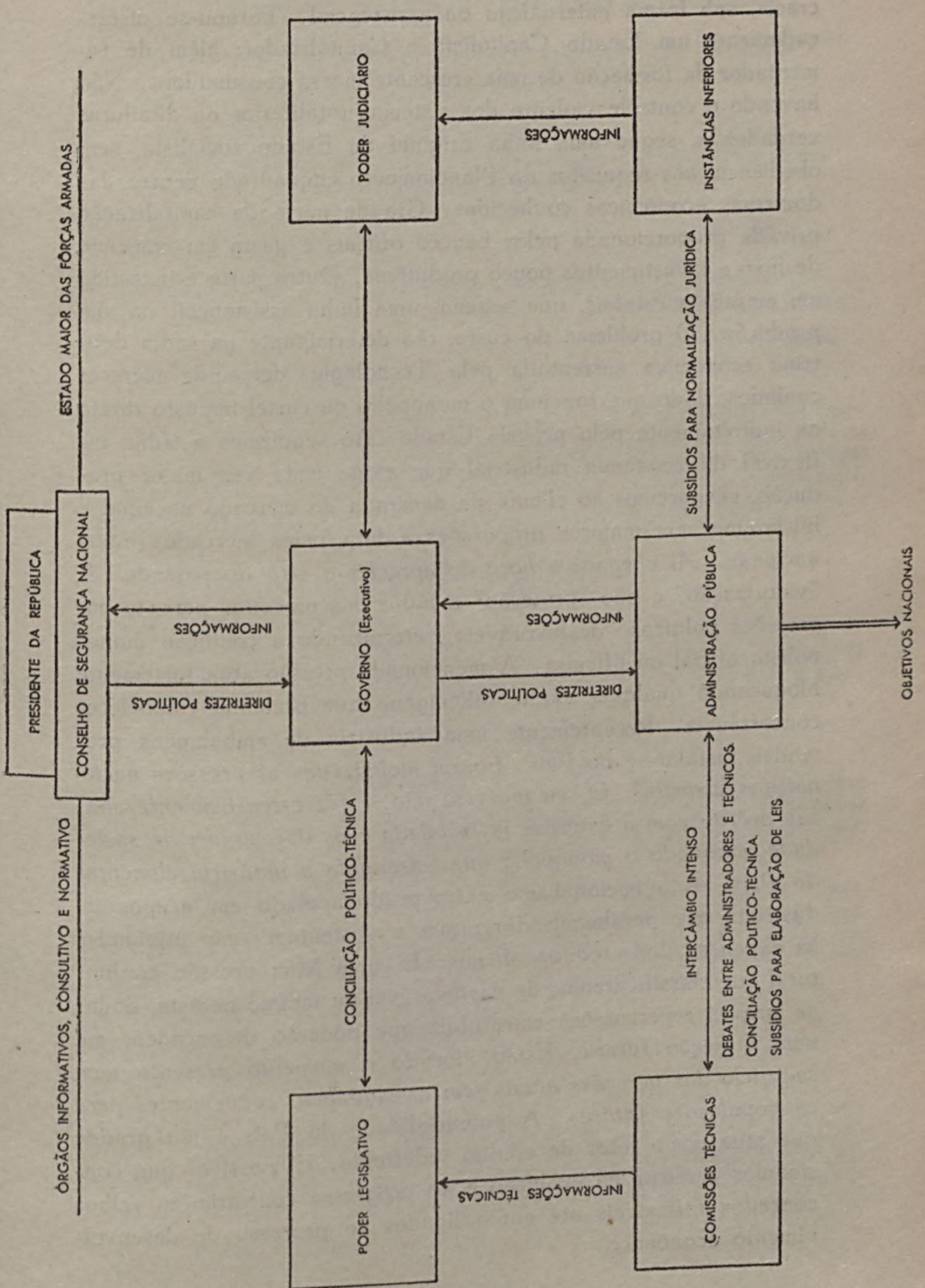


cracia, sob forma paternalista ou assistencial. Tornou-se disfarçadamente um Estado Capitalista e Capitalizador; além de fomentador da formação de uma crescente massa consumidora. Não havendo o contrôle violento dos sistemas totalitários ou ditaduras verdadeiras, segue uma linha original de Estado socialista, sem obediência aos requisitos do Planejamento enquadrado dentro das doutrinas econômicas conhecidas. Grande parte da capitalização privada proporcionada pelos bancos oficiais é gasta em consumo de luxo e investimentos pouco produtivos. Outra parte é investida em emprêsas estatais, que seguem uma linha assistencial na sua produção. O problema do custo, tão determinante na sadia douitrina econômica sustentada pela Tecnologia, deixa de merecer cuidados, dado que funciona o monopólio ou cartel impôsto direta ou indiretamente pelo próprio Estado. Ao seguirmos a trilha inflexível da economia industrial que exige cada vez maior produção, chegaremos ao climax da demanda do mercado nacional e iniciaremos em maiores proporções a luta pelos mercados internacionais. Ai chegará a hora de apreciar o êrro do passado. A "valorização" e não "proteção" a indústrias pioneiras persiste por pressões politicas "desfavoráveis", eternizando a condição monopolista oficial ou oficiosa. A mencionada pressão atua fortemente bloqueando qualquer capital alienígena que pretenda estabelecer concorrência. Recentemente uma indústria de embalagens pretendeu instalar-se no País. Foram mobilizadas as pressões nacionalistas suspeitas. O seu ingresso não se fêz ostensivamente, mas sob acôrdo com a emprêsa já instalada e os dois attuam de so:ieciade mantendo o monopólio que estrangula a indústria alimentat do Pais. E o nacionalismo extrovertido apoiado em grupos industriais que geralmente formaram e sustentam suas atividades às expensas dos créditos oficiais. E' uma Micropressão conjuntural que classificaremos de desfavorável ou mesmo nefasta, dadas as graves repercussões estruturais que poderão desencadear em uma projeção futura. Estão vivendo o momento presente com sacrificio das gerações atuais sem as vantagens convenientes para as populações futuras. A potencialidade do País é tão grande que atua como fator de crédito indefinido. $E^{\prime}$ possivel que con sigamos persistir na evolução e no progresso contrariando velhos conceitos inflexíveis até então ligados ao processo de desenvol-
vimento econômico. 


\section{UM QUADRO DE ASPECTOS CULTURAIS DE EVOLUÇÃO}

\section{A dualidade cultural interna e externa. Os processos contraditórios}

\section{Brasil}

$\mathrm{Na}$ descoberta e periodo colonial

escravidão
A sociedade

Estrutura social e economia semelhantes àquela da pré-história
Eutopa

Pleno Feudalismo

servidão
Capitanias e Vice-Reinado Sociedade e economia feudal
Inicio do liberalismo e do capitalismo autênticos

Servidão

Formação burguesa

Império e República

servidão, colonialismo tipico, inicio do capitaIsmo do Estado.
República após 19.30

Acentua-se o Capitalismo do Estado e as suas funçōes capitalizadoras privadas e de formação de grande hurocracia e formação de massa consumidora.
Esbôço de burocracia intensa, formação a expensas do Estado de uma classe-média e de um capitalismo privado (concessões de serviços públicos, compras de produção e garantia contra riscos) contradição com o liberalismo.

Formação de tıma classe consumidora direta ou indiretamente sob os auspicios to Es tado (tipo paternalista).

Criação de uma classe privilegiada de capitalismo privado a expensas do Estado. Formação de uma classe-média sem as aquisicões culturais e intelectuais necessárias. Monopólios e cartéis proporcionados pelo Estado, que em principio foi o próprio capitalizador em bene. ficio de um grupo social.

Libe:dade de idéias e de pensamentos dentro do domínio econômicofinanceiro do Estado (a grande contrađição).
Capitalismo e Liberalismo. Entrada em campo da Tecnologia. Modificações politicas para neoliberalismo, Democracia Social e Estado Bem-Estar.

Ampliação de uma forte e autêntíca classe média.

Estado Bem-Estar neoberalismo ou Democracia Social facilitados pela posse da Tecnologia.

Estado Totalitário (capitalismo do Estado) caminho para Democracia So. cial passando po: um Socialismo.

Formação de uma classe burocrática e política privilegiada nos Estados Totalitários. Perda gradativa do totalitarismo pela elevação do nivel educacional. 
Define-se hoje o Brasil em uma posição original e experimental para grande parte dos diversos grupos sociais em periodos retardados de evolução e de desenvolvimento. Quebrando as doutrinas politicas e econômicas em proporções especiais caminha em franco desenvolvimento econômico atolado na maior inflação e tendo no Estado o maior formador de sua classe consumidora. Só a forma paternalista atende assistencialmente a um volumoso segmento social, ao mesmo tempo que proporciona requisitos educacionais indiretos através dos recursos que despende com uma massa crescente de funcionários. As condições conjunturais conseguidas sugerem sensivelmente a afluência do capital internacional. O que compromete uma intensa aplicação de capitais alienigenas são justamente certas explosões politicas conseqüentes à incipiência educacional e a uma falta de consciência cultural sôbre os processos sociais de evloução e de desenvolvimento. Dentro do quadro nacional, ao que nos parece, formula-se um terrivel dilema, situando-nos em uma hesitante encruzilhada dos caminhos a seguir. Em nossa área continental ainda encontramos quase todos os periodos de evolução social, desde os fundamentos de uma evolução e desenvolvimento bastante satisfatória até características escravocratas de trabalho. Com o avanço da técnica de comunicações passaram as pressões reivindicatórias a se tornarem mais fortes e sempre presentes, ao mesmo tempo que facilita a difusão cultural indispensável a corrigir os desnivelamentos. Ao contrário, contudo, da marcha regular dos processos de reivindicações segmentares sociais, trouxe o progresso das comunicações uma "imposição" de reivindicações, aceitando, inclusive, atitudes "utópicas estranhas" que propagam soluções fáceis e simplistas. Estas pressões caminham até no estilo revolucionário. O primarismo das conclusões apressadas e das soluções geniais, decisivas, é fàcilmente acessivel no irrealismo dos povos subdesenvolvidos. A própria experiência brasileira, se confirmada sua autenticidade como processo de evolução e de desenvolvimento, precisa ser ajustada a condições e situações especificas de cada povo.

A filosofia do Estado Bem-Estar formado e fundamentado na Tecnologia impunha um progresso violento da produção industrial. Com isto ampliaram-se os objetivos de aumentar mercados consumidores e acesso fácil às fontes de matérias-primas. O Brasil em uma fase intermédia, com uma massa consumidora sempre crescendo e uma população sofrendo de deficiente nível de vida, é o campo apropriado para a disputa internacional. Tentam as ideologias existentes, algumas transformadas em utopias, a conquista da predominância politica e sua resultante, os favores econômicos. 


\section{AS DEFINIÇÕES}

Dois grandes grupos estarão definidos, havendo muitas vêzes associações, com predominância de ações, conforme as finalidades a serem atingidas para conseguir os objetivos. São as pressões de maior vulto, inclusive associadas com processos variados de atividade, fazendo crer identificação com a conquista de objetivos. nacionais.

Macropressóes

- Reivindicações

- Populares

- Politica internacional

- Ideologias

- Utopias

- Místicas

- Doutrinas filosóficas

- Mistos

- Econômicos (ação permanente)

— "Dumping" (ação temporária)

\section{Micropressões}

- Grupos profissionais
- Grupos econômicos
- Grupos religiosos
- Grupos "burocracia" (funcionalismo)
- Grupos científicos
- Grupos associados ou mistos
- Cartéis
- Monopólio
- "Trustes"
- "Dumping"

As Macropressões e reivindicações populares

As reivindicações populares têm sido através da História a grande fôrça propulsora da evolução e do progresso da Humanidade. Mesmo pesando os periodos e fases negativos em que ela é manobrada e dirigida contra os próprios objetivos que persegue, o saldo lhe é sensivelmente favorável. Muitas vêzes a atitude do grupo se define com aquela dos demais grupos movida por uma contagiante manobra de envolvimento, sendo o processo iniciado por um segmento social, agitado e atuante, transformado 
em "opinião pública". Na sua natural irreflexão, inconsciência, imprevisão e improvisação é muitas yêzes levada a se associar com interêsses coletivos menos nobres e conscientemente defendidos por outros grupos de pressão mais bem organizados. As pressões referidas sempre se fazem sentir sôbre um grupo social privilegiado que goza do poder ou da posição de autoridade, manobrando-os de acôrdo com seus interêsses. Os tribunos romanos e os ditadores gregos foram criações suas. Os reis eram selecionados pelo grupo entre nobres e os elementos importantes da classe privilegiada. A pressão das reivindicações populares aproveitava da rivalidade existente entre êles para distinguir um com seu apoio. Na nova posição viam-se na contingência de atender a reivindicações populares para equiparar ou superar o prestigio que haviam perdido. O regime republicano também foi uma típica criação do grupo em tela, visando estimular a dinâmica social, estabelecendo assim correntes de penetração nas diversas camadas e categorias da sociedade. Como vimos, na Revolução Francesa, a burguesia proporcionou o acontecimento para destruir o privilégio da nobreza, o que não evitou que se instalasse uma nova classe privilegiada. Lutando para estender os benefícios da educação, não conseguiu destruir o espirito seletivo que constituia o privilégio da nobreza, fazendo apenas mudar de mãos os direitos aos diversos ramos de ensino. As monarquias que atenderam a tais reivindicações permaneceram de pé. As demais que cometeram outras "perversöes" frente aos interêsses do povo, e não caminharam na senda da democracia social, também se extingui-
ram.

Sòmente a filosofia democrática em sua nova conceituação, com base nos direitos da pessoa humana a par da prerrogativa da representação politica, poderá corrigir os efeitos violentos da pressão das reivindicações populares de nosso tempo. Infelizmente os povos ainda civicamente incapacitados estão ainda impregnados do espírito carismático de seus ancestrais. Decorre disto a aceitação fácil de figuras "salvadoras", "insubstituiveis e necessárias" na direção de seus destinos. Acreditam menos na Instituição e mais nos homens, quando os defeitos mais terriveis são justamente dos últimos. O circulo continua vicioso, quando os representantes do povo ainda pouco evoluído tendem a formar oligarquias politicas com priviégios semelhantes ou similares àqueles da antiga nobreza que sempre combateram. A incipiência educacional aceita fàcilmente as manifestações conclusivas e as soluções simples sôbre seus problemas, sem análise e críticas que as possam fundamentar. Torna-se, assim, prêsa freqüente dos demais grupos da Micropressão, ou aceitam passivamente a integração na Mistica, muitas - vêzes fatalista e conservadora. 


\section{Considerações acêrca de algumas misticas}

Existem místicas religiosas, filosóficas, doutrinárias e mesmo ideológicas. Certas místicas religiosas procuram estabilizar a estrutura social, pelas tradições. O conformismo com a situação e a posição gera um fatalismo prejudicial ao próprio povo. O centro geográfico que sedimentou a filosofia oriental distante, isto é, o oriente médio, berço do cristianismo, constitui flagrante exemplo da Macropressão Mistica. Conseguindo canalizar uma imensa riqueza para seu território, pela mudança da fonte energética das culturas mais adiantadas, para o petróleo, aplicou os investimentos no luxo ostentatário de reduzido grupo, em pedras preciosas, riquezas imóveis e móveis improdutivas. Reagem fortemente a qualquer mudança ou inovação, princípios fundamentais da evolução e do desenvolvimento. A religião maometana é um dique forte contra o "comunismo" assim como a outras doutrinas e ideologias evoluídas ou novas. Foi teatro de grandes preocupações politicas causando substanciais desgastes materiais aos E.U.A. Perderam êstes recursos e tempo ao não se socorrerem de seus centros universitários onde se pesquisam e estudam profundamente as questões sociais e politicas e, especialmente, a Ciência Politica. Não souberam somar com precisão a sua ideologia democrática com a Macropressão Mística religiosa dos povos maometanos.

O misticismo filosófico da China e da Índia foram imenso entrave ao encaminhamento de seu grave problema de superpopulação. São Macropressões antagônicas ao processo de resolucão dos problemas materiais do homem. As resultantes do conformismo e do fatalismo, intimamente integradas na mística religiosa constituem obstáculos tremendos para a evolução e o aperfeiçoamento. Não existe e não pode haver progresso e evolução sem intercâmbio cultural. Como sempre, o meio-têrmo é a posição favorável ao gênero humano. A conservação racional de certos valores tradicionais mantém vivo o espirito e o elo de solidariedade de um grupo social. A resistência incondicional ao processo de transmissão cultural é fatal ao interêsse de qualquer nacionalidade. A Macropressão Mistica pode ser decisiva para - progresso de evolução e de desenvolvimento, supondo-se que sejam objetivos da nacionalidade. A tradicional mistica dos povos antigos pelos reis e imperadores considerados representantes da divindade ou "pessoas divinas" forneceu ao Japão o cabedal preciso para se tornar uma nação industrial, quando consentiu no intercâmbio cultural, sem ferir dogmas religiosos fundamentais.

A Rússia mantém uma pequena percentagem de místicos que "acreditam" no comunismo como filosofia ou doutrina, formando uma Macropressão tendente a conseguir a restrição do consumo 
INTERCAMSIO ENTRE AS COMISSÕES TÉCNICAS dO CONGRESSO E A ADMINIISTRAÇÃO PÚBLICA

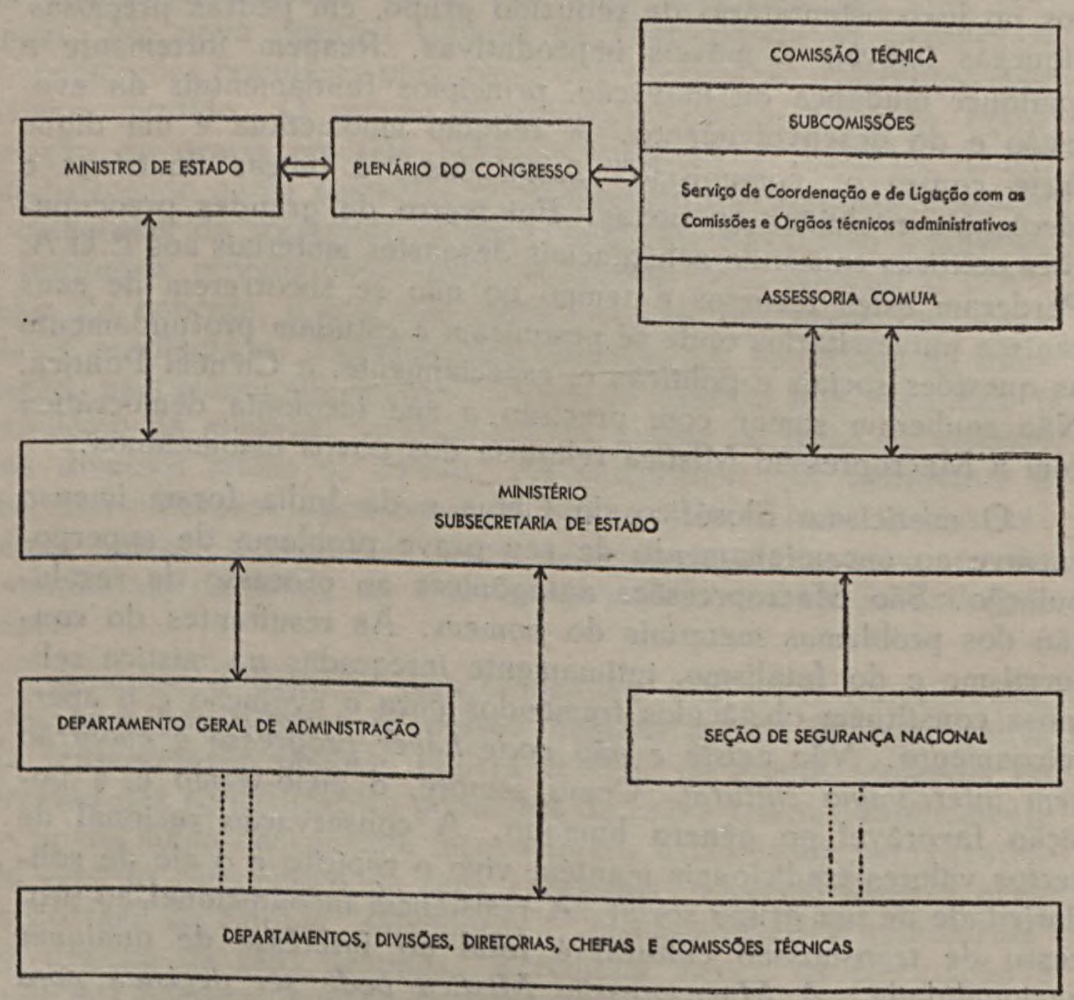


para manter investimentos maciços na área da indústria de base e básica e, na pesquisa científica. Funciona, a seu favor, no campo internacional visando a aliviar aquela pressão interna ligada ao setor bem-estar. Pretende, assim, canalizar o esfôrço de outros povos para atingir os padtões de bem-estar do ocidente. Como a mística é sustentada pela crença, sendo ela vulnerável, nem todos dispõem de constituição individual adequada para mantê-la. Eis por que não convém aumentar muito o seu número, dada a complexidade do contrôle. A Mística Filosófica ou Doutrinária do comunismo na Rússia dispõe de aproximadamente 7 milhões de "praticantes" em uma população de 220 milhões. Têm êles prestado serviços excepcionais no setor educacional escolar. Define-se o grupo dominante por uma ideologia de aumentar progressivamente o Poder Nacional russo e fazê-la seguir o curso de sua história. Antigamente era a expansão territorial agora é a amplitude de mercados e o Império econômico. Para além fronteiras funciona a seu favor a Utopia que encobre a caracteristica recolucionária para vencer tradições e fôrças tradicionais. Existe também um reduzido grupo de Mistica que se entende quanto a idéias, mas diverge quanto a interêsses.

O antagonismo tem servido a uma ideologia em seu aperfeiçoamento, fundamentada na filosofia democrática de vida. A prática mais autêntica desta ideologia é decorrente das três Macropressões mencionadas que contra ela se identifica como uma Utopia.

Vemos, assim, no teatro da vida. os antagonismos, as discussões, a polêmica e o debate favorecendo ao gênero humano nas suas reivindicações.

\section{O Nacionalismo como mistica}

O Nacionalismo pode constituir uma Mistica. Dois grandes países baseiam parte de sua segurança naquela mística. São a França e a Inglaterra. Contudo, seu misticismo é consciente e bem medido não dando motivo a explosões primárias e ostensivas. Quem quet que seja ao planejar a perseguição de um objetivo não "vai dizer a todo o mundo" como agirá, antes de estar seguro de atingi-lo. Nenhuma nação do mundo conseguiu evoluir e se desenvolver sem a colaboração de outras nações. Quanto mais um país se industrializa mais necessita diversificar suas matériasprimas e expandir seu campo de consumidores. A economia industrial tem que ser progressiva. Com a Tecnologia a produtividade tem sempre uma ordem expansiva, sendo em pouco tempo alcançada a demanda territorial. Quanto mais se industrializa aumenta cada vez mais o grau de dependência. Assim racioci- 
nando, torna-se muitas vêzes mais interessante deslocar a mãode-obra para trabalhos mais qualificados, retirando-a dos setores primários da economia. Convém às vêzes resguardar as matériasprimas e procurar importá-las. À medida que evoluiu e se desenvolve, mais um pais necessita dos outros. Decorrendo de tudo isto deduz-se o quanto se torna primária a manifestação de um nacionalismo extrovertido prejudicando interêsses fundamentais de uma Nação que está determinada a se desenvolver. Sendo uma pressão natural pode tornar-se favorável quando adquire a caracterização mística. Por outro lado é uma pressão antagônica quando assume formas agressivas ou intolerantes, prejudicando a politica do intercâmbio cultural.

IDEOLOGIAS E SUA SIGNIFICAÇÃO PARA O PODER NACIONAL

\section{A Conceituação}

Quem conseguiu dar uma disciplinação e desenvolvimento ao conceito de ideologia foi o Professor K. Manheim, que retirou o têrmo do marxismo. Demonstrou que as idéias e as atividades intelectuais de uma época não se desenvolvem obedecendo a uma formulação rigida e com seqüência, mas são determinadas pela evolução social. Daí, ser possível a análise e a crítica dentro da sociologia, das idéias e atividades politicas mais objetivas. Sua conceituação é a seguinte: "são construções conceituadas por meio das quais grupos conservadores preservam a ordem existente". Vemos, assim, que os grupos que ansiavam pelo poder e pela dominação lançam mão da "utopia", sempre bem aceita na constituição biológica do gênero humano. Com tal manobra criam as "ideologias" que representam a tática de conservação do poder que conquistarem.

Assim, as classes dominadas procuram defender-se e passar à ofensiva por outro mecanismo psicossocial, que sendo contraditório à ideologia, está intimamente a ela ligado: a utopia. Em sua obra Power and Society, D. LAssweri. define funcionalmente os dois têrmos: "a ideologia é o mito politico que funciona para preservar a estrutura social; a utopia para suplantá-la". A natureza coletiva, inconsciente, toma tal representação utópica sob forma mística, não dando atenção aos aspectos da realidade e da verdade. $\mathrm{Na}$ dialética utópica encontramos a nutrição própria dos elementos revolucionários, exatamente como atuavam os revolucionários comunistas na era pré-revolucionária, antes da conquista do poder. Logo que isto aconteceu começou a atuar a ideologia, tendendo a conservar os padrões atuais que mantêm a "nova classe de dominantes do poder". Os símbolos utópicos se transformam em ideologia. A ideologia democrática constitui a chave funda- 
mental da conservação de um estado social, cujas transformações, a partir da era liberal pura, vêm sofrendo profundas modificações, definindo-se por transigências necessárias e imperativas para vencer a "utopia" das classes desfavorecidas, ansiosas por transformações. Identifica-se hoje um sistema neoliberal ou neocapitalista outorgando ao Estado atividades e ingerências na esfera privada até há pouco unânimemente condenadas. A função conservadora das fôrças sociais tradicionais tem sido atingida sensivelmente frente ao quadro de evolução social de nossa época. Arnold Toynbee confere às mesmas fôrças a função de conseguir estabelecer normas harmônicas pacificas com a evolução utópica das classes populares, amparando o quadro revolucionário previsivel. A filosofia democrática ambicionada e corretamente praticada por governos, cidadãos e personalidades será capaz de sustentar a estabilidade social de nosso tempo. Tôda vez que as fôrças tradicionais perverterem as manifestações utópicas, não conseguirem a "integração social" de suas atividades e atiudes, será difícil a conservação da estabilidade social. A religião, a universidade e a classe armada precisam rever suas atitudes e suas atividades. Nos sistemas de govêrno, a ética das elites dirigentes comportará a profundidade e a ampliação do campo de "confiança" do povo, deixando êste, voluntàriamente, a decisão da "opinião" para questões mais simples e ao alcance de sua compreensão. Eis por que se torna sumamente importante a formação das elites de nosso tempo, dado que a fonte de Poder Politico está cada vez mais passando às mãos do povo. Se nas eras passadas a "virtude" consistia na conquista e na conservação do Poder, a todo o custo, sendo mesmo tal habilidade a bandeira realmente ideológica, em nossos dias, tomou o povo consciência de sua fôrça e de seu papel na formação e na constituição do Poder. Se os governos eram seletivos e autoritários, hoje só serão autoritários pela confiança e aprovação do povo. No importante jôgo entre imposições da política e determinações da Técnica, em que se evidencia a Arte Politica, adquire esta sempre maior ascendência sôbre aquela, conforme o procedimento de sua elite dirigente dentro dos mandamentos da Ética e da Moral públicas. Assim, a "confiança" adquire maior substância sôbre a "opinião", sempre tendendo a favorecer os interêsses coletivos. Nunca a Tecnologia foi tão necessária para a função de governar os povos, ficando êstes à margem, na sua incapacitação para compreendê-la. Sentindo pelos resultados a incapacidade de suas elites, toma muitas vêzes desastradamente as decisões que julga acertadas. Por outro lado, as elites ignorantes dos processos sociais de evolução entregam ao povo decisões que fogem a sua capacitação, cometendo uma "perversão". E' como que tirar da própria responsabilidade e colocá-la em mãos inábeis e inocentes os seus próprios destinos. 
À medida que as classes trabalhadoras adquirem prerrogativas e situações, ampliam o quadro da ideologia, tendendo sempre a conservação da estrutura social vigente. Mannheim afirmou que a utopia social-comunista se inclina a identificar se com a utopia liberal, pois ambas passariam a admitir o reino da liberdade e da igualdade num futuro remoto. Esta é, aliás, a ideologia das camadas dirigentes russas, para quem o comunismo, reino da igualdade e da liberdade, "foi transferido às calendas gregas".

Em países de evolução e de desenvolvimento retardados as ideologias desempenham um papel de máxima importância. Justamente nêles as classes trabalhadoras ainda não conseguiram integrar-se definitivamente no processo cultural, lavrando dentro dêles atitudes utópicas. À medida que tal processo se estabelece irão elas engrossar o campo ideológico. Nos países evoluidos suficientemente já se encontram elas integradas na massa ideológica A última classe a conseguir tal integração é a agrária, que não acompanha o ritmo de desenvolvimento industrial e tecnológico. $\mathrm{Na}$ encruzilhada em que nos encontramos, a classe burguesa se debate muitas vêzes em atitudes e ações contraditórias. No campo da competição e das lutas, tomou o Estado Moderno a posição de arbítrio. E' obrigado a lançar mão da autoridade para combater uma série de atuações que se definiriam como uma "perversão" frente ao processo de ascensão das classes menos favo. recidas. Resguardando os fundamentos da democracia, poderá o Estado concorrer eficientemente para a harmonia social, evitando qualquer deformação que atente contra os principios indispensáveis que evitarão a solução revolucionária para condições sociais especiais.

\section{A Macropressão da ideologia democrática}

Das guerras que sempre deixam à margem os verdadeiros interêsses do povo têm resultado, na opinião de alguns autores, a satisfação de reivindicações populares, desde os periodos em que já se encontrava politicamente formada a "cidade", isto é, nos séculos que antecederam o cristianismo até os tempos modernos. As revoluções, que nunca se devem a iniciativas populares, são movidas quase sempre por uma fôrça e tendência de transmutar posições de poder e de privilégios. O resultado tem sido o desalento do povo pela formação de uma "nova classe" privilegiada. As revoluções podem modificar conjunturas, mas conservam o processo de evolução sem grandes mudanças, inovações ou evolução.

A revolução se passa sempre dentro das questões politicas, e o povo é sempre caudatário das conquistas aproveitadas apenas 
por aquêles que mudaram de posição. As guerras atingem as estruturas sociais. No último conflito o fato foi comprovado pela repercussão facilitada pelo avanço da técnica de comunicações. Contudo, desde a fase de reivindicações iniciada na diversificação dos sistemas sociais monopolizados pelo "pater-famílias", na Roma antiga, as guerras inicialmente não contavam com servos e escravos. Com a evolução, passam êles a compartilhar diretamente dos conflitos. Os cidadãos e patrões, ao voltarem espoliados em seus interêsses e propriedades, precisavam de maior colaboração. Surgiam novos monarcas e novos tiranos que iriam encontrar na classe privilegiada os maiores opositores. Neste jôgo de interêsses iam sendo satisfeitas progressivamente uma série de reivindicações populares. O processo favorável ao povo dependia muito dos homens a quem estavam entregues os seus destinos? Da qualidade dêles dependiam maiores ou menores concessões. Tulio Sérvio, filho de escravos, criado por Tarquinio, no século 4 antes de Cristo, disciplinou o direito e tornava acessivel ao povo cs segredos do tribunal. Sólon, em Atenas, organizava a hierarquia e competência do juizado. Foram os dois que retiraram o poder de escravidão dos proprietários sôbre os servos através das dividas agricolas. Foi, aliás, a primeira Reforma Agrária caracterizada. O primeiro foi assassinado a mando da filha para pôr no trono o próprio marido; e Sólon, ảo voltar de uma longa viagem, encontrou o Poder nas mãos do tirano Pisístrato. O povo, quando assume a direção ativa dos processos violentos para atender suas reicindicações, tem errado quase sempre. Não é outro o motivo de terem sido os filósofos da antiguidade contrários ao processo democrático de escolha de dirigentes. A partir de Aristóteles, sempre vigorou o sistema seletivo ou a mistificação democrática na escolha de governantes. O longo periodo feudal. com estrangulamento total da vontade do individuo, perpettout-se até o século XIX. Dentro de tal pensamento, girou tôda a atividade educacional que fundamentou a atual civilização. A última guerra provocou modificações sensiveis da estrutura social e politica, firmando o caminho da instalação da Democracia Social e da nova estrutura do Estado Bem-Estar. Houve inclusive uma passagem rápida pelo neoliberalismo ou neocapitalismo. Foi inovado o conceito de democracia. Já oito anos antes da Revolução Francesa, Voltaire clamava pelos direitos da pessoa humana de dispor livremente da escolha que the ditasse a consciência. Isto foi nas proximidades de 1781 . Sòmente em 1945, quando dos fundamentos da formação das Nações Unidas, foram enfatizados os direitos da pessoa humana. Daí em diante começou a se descobrir que a filosofia de vida democrática deve ser norma de vida de cidadãos, de relações entre êles, e com o Estado, e, também, entre Nações. A "mesma oportunidade a todos" não 
foi proporcionada a tôdas as Nações, senão pela fatalidade histórica, a algumas mais privilegiadas. A filosofia democrática fundamenta a Ética e a Moral de nosso tempo, muito bem assinalada no verdadeiro cristianismo. Está justo que se assinale a "qualificação adquirida" pela vontade de cada qual, mas é preciso, também, que se lhe proporcione a oportunidade de satisfazê-la. E' também obrigação daqueles que ascenderam às fases mais avançadas da sociedade, já com direitos, que procurem atender aos que mourejam no periodo primário e instintivo das necessidades, antes de levá-los a compreender as vantagens e a dignidade da liberdade de idéias e de pensamento, desde que se sujeitem a certas restrições indispensáveis ao bem coletivo. Estas são as reivindicações de nosso tempo, e pressões imensas se organizam máxime, na "Ideologia Democrática", que não deverá ser clamada sòmente para conservar os privilégios de alguns, senão para atender a um maior número nas necessidades.

Dentro de uma macroanálise do processo histórico de atendimento às reivindicações sociais pela critica da diversificação e do aperfeiçoamento dos sistemas sociais, pode-se concluir com segurança que a ideologia democrática deixa pelas condições específicas de facilitar inovações e mudanças à margem mais certa e determinante de evolução social. As revoluções têm sido negativas quanto a satisfações das reivindicações populares.

No atual ponto histórico da Humanidade a guerra poderá destruir completamente a civilização atual, que vem sendo construida há cêrca de trinta séculos. Nunca retrocedendo da liberdade de idéias e de pensamentos, a ideologia democrática na sua conceituação nova deverá ser o ponto cultural inalienável de todos os povos. Se o homem cívico tem a obrigação de praticá-la, o cidadão tem o dever de discipliná-la, assim como as elites a responsabilidade e a culpabilidade da perversão de seus fundamentos. As Nações já mais evoluídas e desenvolvidas arcarão com a responsabilidade de proporcionar às demais as condições propicias para conservarem os preceitos ideológicos como sinal de partida para o aperfeiçoamento. Sòmente pelo diálogo, com seus debates, suas discussões, suas polêmicas e a liberdade de fazê-lo será possivel unificar o pensamento na sintese do "análogo" em benefício do gênero humano.

CONSIDERAÇÕES SÔBRE MICROPRESSÕES E CONJUNTURA

\section{Aspectos do processo econômico}

O processo brasileiro de desenvolvimento econômico, antes numa tentativa de firmar-se na doutrina liberal, começou a fugir dos preceitos da verdadeira economia capitalista. O processo de 
evolução histórica, como vimos, atendia nas trocas comerciais a dois aspectos ou duas culturas diversas. O contato mais direto com a Europa nos introduzia a uma cultura e aqui caminhávamos com outra bem diferente, procurando o reajustamento natural das condições e particularidades nacionais. Não tendo passado pela fase capitalista-liberal autêntica, tivemos dificuldade de conseguir a Tecnologia com que poderia ser estruturado, na moderna conceituação do Estado, a democracia Social. Contudo, a crescente massa populacional, com nivel escasso de poder aquisitivo, era impressionada pela vida de bem-estar de outros povos mais evoluídos. A técnica de comunicações com seu extraordinário progresso tornou o mundo pequeno e está forçando uma sincretização cultural, levando-o a constituir uma "unidade". Nosso país sofreu logo a pressão violenta das reivindicações populares e teve que instituir o Estado Bem-Estar, tendo apenas como fatôres positivos para isto o potencial natural escassamente aproveitado, uma população vultosa e sempre crescente figurando uma possibilidade consumidora excepcional e uma fase intermédia de evolução e de desenvolvimento. Os quatros acontecimentos, já criticados, que mudaram o caráter nacional - a queda da França, em 1870, as duas últimas guerras e a crise econômica norte-americana de 1929 concorreram para estimular nossa capacitação de produção. Com tais eventos a mentalidade produtiva havia entrado no caráter nacional.

Para cumprir as obrigações inerentes ao Nôvo Estado, em condições diversas daquelas que ditavam as doutrinas econômicas, houve necessidade de ampliar sistemas sociais assistenciais. Como empirismo e como experiência, quase sempre por razões politicas. Criou-se um paternalismo do Estado e um forte sentido de agente capitalista e Capitalizador. Criou-se um excelente campo de aplicação para poupanças externas.

Por outro lado, o Estado intervinha sensivelmente nos campos econômicos, especialmente, nos que sofriam as pressões internacionais na politica de preços. Sob vários aspectos tal procedimento necessita análise e crítica mais aprofundada para julgamento sereno. A estrutura social caminhava para uma situação que determinava esta maior ingerência do Estado, se bem que a conjuntura, mais apegada aos processos doutrinários estabelecidos. estava contraditando-a.

Evidentemente a ação pioneira do Estado em assunto para o qual ainda não havia amadurecido a cultura própria, pois que as condições fundamentais faltavam para a formação do Estado Bem-Estar, haveria de resultar em percalços, distorções, desajustes e combates acirrados por aquêles que se atinham a doutrinações clássicas. Praticamos uma filosofia democrática, com razoável liberdade de idéias e de pensamento, e ao mesmo tempo instituimos 
uma economia quase tôda fiscalizada, controlada, manipulada, influenciada e mesmo como formada pelo Estado. No pensamento e na ordem jurídica somos uma Democracia Social e na ordem financeira e econômica somos ou caminhamos para um Estado Totalitário. Eis a contradição que mais adiante iremos criticar.

\section{As Micropressões da Conjuntura}

Evidentemente não seria possivel analisar aqui tôdas as Micropressões conjunturais. Algumas, contudo, serão objeto de exame. Com mudança do caráter nacional ganhou o mercado nacional maior ânimo de produzir o que os acontecimentos inter nacionais encontravam dificuldade em nos fornecer. A politica estava dominada pelo grupo agrário que drenava do exterior grandes capitais. Começaram as pressões para que o govêrno tomasse a si a responsabilidade de "proteção" dos produtos agricolas. No convênio de Taubaté de 1907, iniciou-se a fase de valorização do café. Sendo produtores em quantidade e não em qualidade, a nossa atuação serviu para que outros países começassem seu plantio. A Colômbia inicioura no ano seguinte. Dai por diante, conforme os prognósticos de Rodrigues Alves, nunca mais houve na produção e comercialização do café a exclusiva ação da economia privada. A pressão tem continuado até nossos dias, levando o govêrno a retirar da economia agrícola, neste setcr, boa parte de seu resultado em moeda forte. O açúcar vem obtendo maciços financiamentos desde 1922 . A pressão dos produtores tem-se feito sentir a ponto de disporem de um cartel ou monopólio oficial. A técnica atrasada tem que acompanhar o preço que possa compensar o seu custo elevado. Por outro lado, a parte industrial mais adiantada é favorecida pelo preço de venda impôsto pelo monopólio oficial, livre de qualquer concorrência e de qualquer risco. E' uma pressão prejudicial aos interêsses da futura estrutura econômica dó País, quando fôr forçado a colocar no mercado internacional os seus excedentes de produção. No momento existe cêrca de $30 \%$ de superprodução que necessita subsidio governamental para ser exportado. O Instituto do Açúcar e Álcool é o órgão oficial destinado a valorizar e controlar o monopólio estatal em benefício de um grupo de produtores. O lógico seria a sua extinção e formação de uma Cooperativa de Produtores de açúcar.

A partir de 1930 começou a dominar na política nacional o grupo industrial. Este setor da economia impulsionado pela expansão do mercado consumidor e pela taxa desfavorável de câmbio forçava a necessidade de indústria de base e básica para facilitar a sua expansão. O sinal de partida foi dado pelo setor siderúrgico, pela iniciativa oficial apoiada pelos interêsses de alia- 
dos na crise internacional de 1945. No mesmo passo foi conseguida a Petrobrás para a pesquisa e refino do óleo, encaminhando-a a Política para o monopólio estatal. A indústria elétrica que já demonstrava sinais de grave descompasso com a expansão industrial, retomou seu ritmo, parecendo atender à demanda nos próximos cinco anos. Neste setor muito tem contribuído o investimento estrangeiro.

A indústria automobilistica teve tratamentos excepcionais para ser instalada no País. Ao contrário de sua atuação na economia mais livre de seus paises de origem, ela não assumiu responsabilidade do imenso capital de giro que exige a sua comercialização. Pelo seu crédito concorre com as necessidades de capital nacional, desviando para seu campo, grande absorvente de capital, os recursos bancários do País. O ponto de seu maior favorecimento foi a vantagem cambial para importação a câmbio favorecido de peças e equipamentos, para atender um compasso de espera na nacionalização total do veículo. Estas vantagens proporcionaram e ainda o fazem grandes fortunas particulares, algumas em mãos dos politicos que, com a bandeira patriótica, conseguiram um excesso de vantagens fundamentadas nas leis. Um carro nacional de marca e tipo igual é vendido por preço três e quatro vêzes maior do que em seus países de origem. Esta pressão continua para promover as reformas. Constitui no momento, talvez, o grupo econômico de maior importância do País. Analisando e criticando sob o ponto-de-vista conjuntural. apresenta sérias deformações canalizando recursos para um grupo econômico amparado pelas leis de proteção. Num exame com mais profundidade e no ângulo estrutural. é uma das atividades mais favoráveis ao processo de evolução e de desenvolvimento do País. A fôrça econômica vegetativa é extraordinária. É um exemplo típico de julgamento divergente, ao ser encarada pelos aspectos conjuntural e estrutural.

\section{O Nacionalismo}

O Nacionalismo pode ser analisado e criticado tanto como uma caracterização estrutural como conjuntural. No primeiro caso é favorável ao processo de evolução e de desenvolvimento, podendo atingir uma posição excelente se explorado sob a forma ideológica ou mística. Na estrutura, o sentimento nacionalista é caráter e atitude consciente e cultural avançada. Funciona como uma Moral social, concentrado no sentimento de cada cidadão para explodir no patriotismo nas ocasiões oportunas. Em que pesem tôdas as discordâncias, polêmicas, disputas, discussões e dissensões sociais, é êle, encarado como pressão estrutural a fôrça decisiva para união e solidariedade quando em perigo a cultura comum. Sendo um sentimento consciente, está êle inserido dentro 
da próprio integração pessoal de cada qual. As ações nacionalistas devem ser permanentes e continuas quando identificadas na sua caracterização estrutural, visando a uma determinação de evoluir e de progredir $\mathrm{L}$ Sendo uma concentração individual, age pela e. para a comunhão coletiva formando um só espirito e um só pensamento. E' uma característica perfeita de moral social, e, como ela, perfeitamente interiorizado.

O Nacionalismo extrovertido, ostensivo, agressivo e intolerante tem caracteristicas conjunturais, só compreensivel em sua manifestação como impulsionador da sua ação, o patriotismo. Precisa ser proporcional, dosado, consciente, determinado, oportuno e amplo. Sendo ostensivo, sem motivos, tornar-se vulgar, confor ma-se como uma válvula de escapamento que faz diminuir sua concentração interior. Pelos "escapes" desnecessários perde a sua "pressão importante". Em verdade, quando procuramos disciplinar uma gama de procedimentos para perseguir um objetivo, não deveremos dizer a todo o mundo como vamos atuar para consegui-lo, salvo se a consecução do objetivo estiver assegurada. O objetivo Nacional atual é evoluir e desenvolver. Nunca qual quer Nação o conseguiu sem a ajuda de outra. Ora, se dermos demonstrações ostensivas de um sentimento comum a tôdas as Nações, psicològicamente, pode supor se a hostilidade. Por outro lado, os investimentos qualitativos exigem mais segurança do que muito lucro, e os demais atuam subornando, deturpando, mistificando e visando a lucros exagerados a curto prazo.

Por outro lado, na conjuntura, sua manifestação pode servir. de jôgo politico para conseguir campo favorável de expansão de mercados ou acesso fácil a fontes de matérias-primas a grupos alienígenas cumprindo a determinação histórica de aumentar o seut
Poder Nacional.

Assim, pois, o Nacionalismo é ıma Pressão Nacional, Estrutural, Ideológica e Favorável. O Nacionalismo extrovertido, político-partidário, inadequado, inoportuno e vulgarizado é Misto, Conjuntural, Revolucionário (às vêzes) e Nefasto ou desfavorável. Nas páginas que se anotarão mais adiante veremos quanto seria necessário o Nacionalismo sadio e como será bastante prejudicial ao processo específico das condições brasileiras de evolu1ção e de desenvolvimento. O Nacionalismo ostensivo e extrovertido.

\section{O Setor Transportes}

As pressões profissionais ligadas ao setor transportes em certas áreas, examinadas na caracterização conjuntural podem ser consideradas como um estrangulamento do processo econômico nacional. Todo setor transportes tem apresentado grande expan-. 
são, ao ser analisado sob o ponto-de-vista global. Contudo, sua forma tem sido inadequada. Enquanto o ferroviário aumentou $50 \%$, o rodoviário quintuplicou. A qualidade e a quantidade do serviço de cabotagem é alarmante, podendo ser calculada em um aprove:tamento de $25 \%$ apenas. Os portuários pela sua organização e atuação politica têm conseguido os favores sociais de remuneração acima de tôdas as demais profissões. Cada estivador é geralmente proprietário do cargo e o arrenda em duas a quatro mãos diversas. Tal revelação é fato comumente verificado. O "proprietário" geralmente se entrega a outras atividades, não sendo estranhas aquelas ligadas ao contrabando. E' uma Micropressão conjuntural nefasta ao processo democrático de atender dentro da justiça social. Sob o aspecto estrutural, tanto sob o aspecto de ponta-de-lança das reivindicações populares pode ser considerada uma Micropressão natural, como, pela sua desorganização, força a expansão do setor rodoviário. Este por sua vez, estabelece uma Micropressão natural forçando a construção de estradas pavimentadas e expandindo a iniciativa privada pela demanda sempre crescente. A concorrência que já se estabeleceu ainda favorece o preço de custo frente a proporções naturais. Aliás, no que respeita à luta entre o sistema ferrovário e o rodoviário, o assunto não constitui especificidade da conjuntura brasileira. E' conveniente ressaltar que a técnica universal que orienta a exploração do petróleo, organizando inclusive um cartel, tem conseguido manter preços acessiveis. Não fôssem as gravaçōes fiscais, talvez fôsse possivel equiparar os preços nos dois sistemas citados. Na conjuntura brasileira seria excepcional se fôsse conseguido estabelecer uma normalidade de serviços e custos na navegação aquaviária. A Micropressão profissional tem $\sim$ se feito sentir no sentido contrário. A proporção nos preços dos diversos sistemas de transportes é a seguinte:

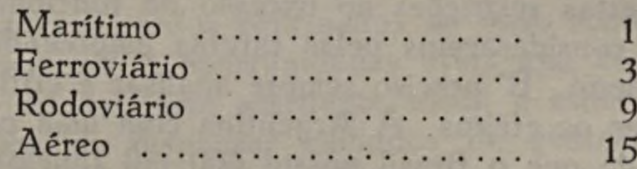

Desde já, sem maiores bases para discutir, poderemos verificar que a proporção do maritimo para 1 e do rodoviário para 9 está longe de significar a situação existente no País. Quanto ao ferroviário a observação é a mesma. Por todos os fatos apontados o sistema rodoviário figura uma pressão forte contrária à expansão dos dois sistemas citados. Como contrapartida, os péssimos serviços do sistema maritimo têm contra êle a Micropressão profissional estranguladora da economia nacional. A disparidade, pela análise e critica conjuntural tende a ser agravar. Sòmente 
por um serviço razoável será possivel conseguir alguns resultados favoráveis. Contudo, ainda no aspecto conjuntural, tal situação exerce forte pressão para aumentar a rêde de estradas pavimentadas, por onde são transportadas mercadorias inadequadas pelo pêso e pelo valor. A pressão tem caráter politico, dada a repercussão de iniciativas próprias como pela flexibilidade dos investimentos. Por outro lado, o tempo de execução facilita a demonstração de atividade administrativa, prestando-se bem para promoção política pessoal.

Analisando e criticando sob o aspecto estrutural, atendendo-se ao sentido de projeção futura, o reajustamento será uma questão de tempo e de madureza cultural. Nesta ocasião verificaremos que o País estará enriquecido com uma extensa rêde rodoviária pavimentada, por onde transitarão mercadorias adequadas. Vemos, pois, dois aspectos inteiramente contrários da Micropressão profissional dos transportes no Brasil. Um desfavorável e outro favorável. Aliamos, assim, mais um exemplo de antagonismo e contradição no processo social de evolução social.

\section{A Micropressão do funcionalismo público}

Muito se fala no excesso de funcionalismo público ou na política de clientela. Contudo, poucos têm analisado o problema nas suas causas, fixando-se apenas nos efeitos. Aliás isto é vício de culturas pouco amadurecidas. A consciência cultural acêrca do assunto ainda é bem incipiente. Eis por que ao definirmos cultura sempre assinalamos tal deficiência de conceituação, como se segue:

"Cultura é um conjunto de realizações e estado de consciência próprios que mais aproximam um povo da meta de suas aspirações e objetivos".

T'emos certas restrições ao excesso de funcionários públicos no Pais. Se considerarmos pelas tarefas empreendidas o raciocinio é verdadeiro. E' preciso sempre analisar e criticar as causas antes de julgar os efeitos. A Argentina com uma populaçäo três vêzes menor do que o Brasil possui 600 mil funcionários, contra aproximadamente $500 \mathrm{mil}$ de nossas estatisticas. O Uruguai cêrca de 70 mil com menos de 3 milhões de habitantes. Os dois países irmãos apresentam uma taxa aproximada de $3 \%$ em relação à população e nosso pais $0,8 \%$.

Qual a causa principal da quantidade excessiva de funcionários

Se de fato há excesso, nós o compreendemos em ordem relativa. Via de regra a percentagem da receita despendida com o 
funcionalismo público é da ordem crescente, em certos casos de $80 \%$ na esfera estadual. No serviço público federal parece situar-se em $40 \%$, incluindo autarquias. (Exceto classes armadas). Ao contrário do que se pensa existe subemprêgo e não pleno emprêgo, como panorama da mão-de-obra do País. Há disponibilidade de trabalhadores braçais, mas falta tremenda de mão-de-obra semi e qualificada. Isto é o mesmo que a revelação da falta de uma Política educacional efetiva, e não a execução sob forma de "campanhas". Só isto basta para revelar a falta de Planejamento no setor educacional. Uma "campanha" seria compreendida como uma revisão sectorial de um Planejamento, identificada como um "reajustamento", que a imaturidade da cultura nacional chama de "reformas de base". Estas nada significam, pois que o processo de evolução e de desenvolvimento é "uno, sinérgico, coordenado, entrosado, interdependente entre fatôres e categorias". Já a nossa definição de governar "equacionar problemas" mostra a importância de dispor do conjunto dos dados para o Planejamento, que por sua vez é "prover e prever". A Micropressão no profissionalismo da esfera oficial decorre da capacidade falha de equacionar o problema da educação no País. $\mathrm{O}$ empreendimento privado seleciona os mais capazes e deixa à margem a grande massa pouco qualificada. Esta faz pressão junto ao político para conseguir um emprêgo público. Nada sabe porque nada aprendeu. Contudo, na determinação biológica vai constituir familia e deixará uma geração em condições às suas. Se o Estado tomar a set cargo a qualificação profissional, despenderá em cada série profissional e técnica uma elevada quantia, dado o custo alto dos serviços oficiais. O emprêgo constitui uma modalidade assistencial e um esfôtço educacional indireto. Quando ingressa no serviço público, o funcionário "amplia e qualifica" seu universo social. Esta mudança de posição social dá-lhe oportunidade de atender e encaminhar a própria geração, aquela dos parentes e amigos, todos confinados ao meio social anterior, nos meios educacionais e oportunidades afins que encontra em seus "contatos". Atuou como assistente social e especificamente educacional, além de dispensar cuidados de geração e nutrição à familia. O Estado, se arcasse diretamente com tal responsabilidade, talvez despendesse mais do que o simples ordenado. Quem ainda não atendeu à solicitação de algum contínuo ou burocrata ao comparecer à repartição para interêsses particulares?

O processo de urbanização é importante como fator para facilitar a luta educacional. A taxa brasileira é baixa, chegando apenas a $5 \%$, salvo um ou outro Estado, como o do Rio de Janeiro, com $50 \%$. Na situação brasileira, tal nível já é chamado êxodo rural, porque o fato se identifica como uma entidade patológica social. Aquêles que deixam o meio rural não são substi- 
tuidos pela Tecnologia e sem capacitação vão engrossar os marginais profissionais dos meios urbanos. A Micropressão aumenta cada vez mais quando estamos com $u$ in indice demográfico de $3,1 \%$, ou um dos maiores do mundo. A geração surgida do funcionalismo público está capacitada para as diversas profissóes.

A Micropressão dó funcionalismo público fôrça o govérno a procutar os recursos onde êles se encontram. Nas condições dinâmicas do movimento social e econômico do País, qualificando-se como uma vasta região pioneira, é muito dificil disciplinar bem a distribuição de rendas. O impacto sôbre a Receita obriga a que as emprêsas privadas procurem na Tecnologia a maneira de obterem melhores lucros, dado que o govêrno solicita cada vez mais as medidas fiscais. O fato é que até agora a expansão da produção industrial e dos negócios demonstram que a capacidade econômica ainda está longe de esgotar-se. Ao que nos consta, o carioca despende 17 mil cruzeiros, por ano e "per capita", de impostos e o paulista situa-se nas imediações de $5 \mathrm{mil}$. Sendo o Estado da Guanabara uma "cidade" fundamentalmente burocratizada, verificamos, neste ano, um aumento de Receita pública,
de aproximadamente $40 \%$.

O impôsto indireto é uma injustiça social sensivel, sabendo-se, outrossim, que ao funcionalismo público é difícil esquivar-se ao pagamento do impôsto mais justo de todos que é o de renda. Pois bem, em fontes ligadas à repartição que o arrecada, declaram que a fraude lesa o Tesouro em $50 \%$ da atual arrecadação.

O volume físico de serviços públicos, cremos, não atinge a $20 \%$ do que poderia produzir. Contudo, é preciso ressaltar que apenas nesta percentagem existem os funcionários concursados. O longo periodo de govêrno pessoal atendeu quase sempre sem as provas de seleção. Em virtude disto, sempre houve há alguns anos o desinterêsse para a educação profissional ou técnicas especializadas. A dactilografia que deveria ser a prova eliminatória, ou uma delas, para a burocracia, encontra no serviço público uma das mais sensiveis deficiências. A prova de seleção como postulado constitucional apresenta um fundamento da democracia que é a "mesma oportunidade a todos", correspondendo a moral social convencional de "cada qual ter e fazer o que lhe compete". O procedimento contrário equivale a uma mistificação da ideologia que nos rege a uma "perversão" frente aos interêsses populares.

Passamos assim em revista perfunctória ao problema do funcionalismo público, como Micropressão, examinada, analisada e criticada sob caracteristicas conjunturais desfavoráveis e estruturais
favoráveis. 
PARADOXOS E ANTAGONISMOS DO PROCESSO SÓCIO-ECONÔMICO BRASILEIRO DE EVOLUÇÃO E DE DESENVOLVIMENTO

\section{A Compatibilidade e a Eficácia na conjuntura brasileit a de desenvolvimento}

A determinação de desenvolver deve constituir no momento - Objetivo Nacional Atual de maior relevância. A saltarmos da fase liberal e capitalista autêntica ficamos inferiores na possibilidade de lançar mão suficientemente da Tecnologia. Em verdade tal condição favoreceu as Nações mais evoluidas, algumas, é bem verdade, tão novas como nós. Dispuseram elas, contudo, de conjunturas favoráveis na tradição histórica de herança como em um verdadeiro sentido de transmissão cultural, quando nós labutávamos na retração, sendo teatro de uma economia diversa e atrasada frente àquela dos demais paises. Inicialmente e com cautela sofremos de uma verdadeira alienação cultural sem qualquer vislumbre de consciência cultural de adaptação. Tanto no processo econômico como no social caminhávamos diferentes do que o mundo já conhecia como verdadeira doutrina da riqueza. Tal impacto nos atingia em todos os sistemas já diversificados. Quando estávamos na economia baseada no braço escravo, já a Europa saía do faudalismo. Quando começamos a entrar neste, já no continente referido esboçava-se o Estado Liberal-Capitalista e o espirito tecnológico. Fomos logo contaminados pelas idéias novas de evolução social sem que estivéssemos fortalecidos pelos meios advindos do liberalismo. O grande potencial que nos foi legado favorecia nossas idéias de acompanhar os passos que deram lugar ao Estado Bem-Estar ou Democracia Social. Poucas Nações dispõem do potencial territorial do Brasil e de uma imensa capacidade de consumidores, como nós. Contudo, a doutrina econômica exige a capitialização que, na sua autenticidade, se define na poupança. Para haver incentivo de capitalizar produzindo é necessário o consumo. Torna se, porém, imperativa a Tecnologia. Daí deduzimos que precisamos a compatibilidade e eficácia. Na primeira ressaltamos a importância do jôgo do consumo e da acumulação: A propensão para o consumo material gera a vontade de consumir, resultando, outrossim, no desejo de acumular. Este constitui a "vontade de economizar" na feliz expressão de Arthur Lewis (The Theory of economic Growth). A cultura adequada ao desenvolvimento econômico, segundo Goldschmidt (WALter GolDSCHMIDT), (The interrelations between cultural factor and the acquisition of new tecnical skills) é aquela que satisfàz as necessidades de bem-estar físico, e segundo êle, continua satisfazendo indefinidamente essas necessidades, oferecendo ao grupo social as satisfações necessárias para o ajustamento da 
personalidade de seus elementos no contexto do seu próprio sistema de valôres; "desde que não explore, física ou psicològicamente, alguma outra população ou segmento de população". Três atitudes devem ser consideradas para estabelecer condições determinantes de desenvolvimento, dentro do conceito de Segurança Nacional. Neste último, torna-se necessária a previsão do futuro quando se complicam e se tornam complexos os problemas internacionais de uma Nação. Nós queremos o Brasil sempre e cada vez maior. Não seria demais recordar aqui as palavras de Tobias BARreto: "Não somos nós que temos tudo a esperar do futuro; é o futuro que tem tudo a esperar de nós".

$E^{\prime}$ preciso tomar consciência de que o julgamento decorrente da análise e da crítica da conjuntura não é o mesmo daquele ligado à estrutura. E' muito natural e justificável que o segúndo seja mais do campo dos cientistas e pesquisadores, demonstrando conclusões e resultados contraditórios, porém mais verdadeiros. Eis porque afirmamos que, no ponto histórico do momento, não verificamos qualquer crise brasileira, seja social, econômica ou moral. Os acontecimentos e fatos ligados à conjuntura, mais salientes e vibrantes, são semelhantes àqueles por que passaram tôdas as Nações já em fase evoluida e desenvolvida de hoje. O Brasil faz a sua história.

As três atitudes determinantes para o desenvolvimento são as seguintes:

a) atitude em relação ao consumo de bens econômicos;

b) atitude em relação à acumulação de bens;

c) atitude do povo para se desenvolver.

A atitude em relação ao consumo scfreu uma série de importantes modificações ligadas intimamente à mudança gradativa do caráter nacional a partir do descobrimento. Quando na Europa exigiam as riquezas e os produtos das novas terras descobertas, funcionava a estrutura feudal de desenvolvimento e o processo de evolução social ditado pelas reivindicações populares. Para o Brasil vieram os aventureiros e exploradores que nunca pensaram em formar aqui uma nação. Não havia pròpriamente duas culturas em choque, dado que o contato era das cúpulas sociais aqui existentes, comungando de interêsses comuns. Assemelhava-se esta fase da evolução brasileira àquela da pré-história, ficando marginais, apenas como fôrça de trabalho, o elemento escravo. A medida que a Europa saia gradativamente do feudalismo e entrava na economia liberal, caminhávamos com muita lentidão para o feudalismo. Assim, "enquanto voltados para o exterior" tomávamos contato com uma cultura mais evoluída, aqui permaneciamos em 
fases bem mais retardadas. O Brasil de verdade, que era seu. povo que aqui surgia "vivia escondido e se evitava que fôsse mostrado".

\section{Doutrinas econômicas e processo brasileiro de evoltçãa}

Ao se iniciar a fase de industrialização em pleno liberalismo econômico, acumulavam os países da Europa as riquezas "produzidas pelos colonos de além mar". As massas surgidas com a era industrial que despontava, em virtude de sua fraqueza, organizavam-se e tomavam a dianteira do povo nas reivindicações. Aumentando o consumo e "a vontade de gozar o progresso", atirou-se o liberalismo nas pesquisas científicas e no aperfeiçoamento da técnica. Contudo, a cultura, com que tinhamos maiores contatos e da qual dependiamos, não tinha pendores industrialistas, e, sim, apenas mercantilistas. Por outro lado, Portugal, seguindo a linha de dependência politica da Inglaterra, evitava que suas colônias esboçassem qualquer manifestação industrial. As fazendas permaneciam em uma economia fechada, defendendo-se assim dos preços elevados das manufaturas inglèsas que via Portugal rumavam para o Brasil. Além da tradição avêssa ao industrialismo, nos encontrávamos na defensiva contra a pressão política e econômica. O caráter brasileiro ainda mais se tornou firme na admiração pela estética em prejuizo da utilidade. Tal economia fechada resultava na restrição do consumo, incentivo importante para a produção. O "complexo colonial" que Inácio Rangel denominou ao fato de as fazendas se tornarem núcleos de fabricação dos artigos de consumo indispensáveis, como roupagens, calçados, ferragens, etc., haveria de fazer fracassar mais tarde as iniciativas tendentes a instalação de fábricas. Até 1875 haviam fracassado muitas tentativas de indústria de tecidos. Nossa elite, por outro lado, assimilava inconscientemente a cultura européia e procurava imitar exatamente o que lá se praticava, especialmente, na educação escolar. Esta, aliás, foi a mais longa e perniciosa alienação. Afetava ela o setor importante de um país que necessitava "criar uma consciência cultural própria" de sua vida e de seus problemas.

Por outro lado tornava-se imperativo que vencesse a tremenda herança tradicional avêssa ao trabalho técnico e à pesquisa científica, ligadas à produtividade, desde que nos era dado presenciar a vitória material no setor mercantilista. Podemos dizer que quatro fatos internacionais marcaram a mudança do caráter brasileiro. O trauma sofrido pela França em 1870 , as duas últimas guerras mundiais e a crise norte-americana de 1929. Não falaremos da Revolução Francesa, pois que dela recebemos os 
reflexos de sua repercussão sôbre outros países. Tais acontecimentos vieram-nos demonstrar que poderiamos viver bem e evoluir, criando, inovando e substituindo aqui quase tudo que nos enviavam do exterior para satisfazer nossas necessidades naqueles pontos históricos considerados.

A partir da Revolução Francesa, em que a burguesia levou - povo a se revoltar contra os privilégios da nobreza, estava selada a sorte do feudalismo na Europa. Em verdade, como sempre acontece, o povo tomou parte, utòpicamente, no acontecimento, desde que os privilégios passaram a ser gozados pela nova classe que se instalou no poder. Contudo, serviu a advertência para que as antigas monarquias se voltassem para as reivindicações populares, tendo permanecido de pé aquelas que não cometeram "perversão" frente aos interêsses e aspirações populares. Ainda no liberalismo, ampliou-se e tornou-se mais sensivel a participação do povo na direção de seus destinos. Aumentou o número de consumidores pela garantia que o direito dava da "igualdade de todos perante a Lei", forçando a "vontade" de adquirir posição pela posse dos bens materiais. O respeito pela propriedade privada foi uma alavanca ponderável para a evolução e para o progresso.

Em tal ponto histórico, instalou-se o espirito tecnológico e mais tarde a Tecnologia. A febre de capital e de capitalização para atender aos reclamos dos novos povos incorporados na vida internacional e portanto consumidores, explorados contudo na discrepândia de preços entre produtos primários e matérias-primas de um lado, e do outro, as manufaturas, forçava uma intensa poupança. Nesta altura a situação econômica de Portugal era péssima quando reinava D. Pedro II. Por razões históricas já descritas, Portugal e sua colônia, o Brasil, não tinham pendores para acompanhar a nova era econômica que se instalava intensamente anos após. Firmou-se ainda mais a situação quando John Methuen conseguiu passar para um Tratado, a ascendência politica e dominio econômico que a Inglaterra tinha sôbre Portugal. Firmou se o Tratado de Methuen em 17 de dezembro de 1703. As vantagens foram excepcionais para a indústria de tecido inglêsa a trôco de uma exportação controlada e financiada de vinhos. Coincidiu tal época com a exploração do ouro no Brasil. Uma têrça parte do metal existente no mundo, na ocasião, ou, 1 milhão de quilos, foram drenados para a Inglaterra através de Portugal. Tal pressão internacional fêz sentir seus efeitos em nosso pais até meados do século XIX. Esta Macropressão politica e econômica histórica reforçou as tradições negativas mercantilistas do povo brasileiro em plena fase da era tecnológica, nos alicerces de sua fundação. 
Os acontecimentos já mencionados conseguiram reformular o tipo do caráter nacional. Enquanto a Inglaterra com o ouro do Brasil estruturava a sua economia liberal e lançava as bases da Tecnologia, D. João V, em Portugual exibia e ostentava luxo oriental em sua côrte. Portugal passava da penúria dos reinados de Pedro II e D. João IV, para a maior folgança mal empregada que se conhece.

Os investimentos acumulados no capitalismo-liberal e a sua criação, a Tecnologia, iriam permitir ao Estado mudar a sua estrutura, intervindo mais na economia privada e na distribuição de riquezas, especialmente, proporcionando a um maior número a possibilidade de concorrer livremente, com maior capacitação, aos postos mais elevados da escala social e politica. Estava caracterizada a Democracia Social. Os segmentos sociais organizados começaram a lutar por maiores reivindicações e o Estado foi ampliado e aperfeiçoando o seu sistema assistencial. Todos os recursos precisavam ser mobilizados dentro da nova técnica para atender as reivindicaçóes cada vez maiores, levando o Estado Moderno a controlar as fôrças sociais tradicionais, sobretudo aquelas que dispunham de poder econômico. Novas leis apareceram condicionando a posse da propriedade em seu uso, ao bem coletivo. (Sobretudo a terra). Surgiu o Estado Bem-Estar.

Pois bem, sem passar o Brasil pelo capitalismo-liberal autêntico, sem explorar colônias, sem a posse plena da Tecnologia, resolveu experimentar o Estado Bem-Estar. No momento progride satisfatòriamente e evolui, lançando mão do crédito que lhe proporciona o imenso potencial natural ainda pouco explorado. Certas dividas estrangeiras no montante de 2 bilhões de dólares aproximadamente ou 800 bilhões de cruzeiros ou, mais de uma vez e meia a Receita Pública Federal, tiveram dilatados seus prazos de vencimento. Esste fruto da poupança alheia está servindo heròicamente no ponto critico do desenvolvimento. As inflações maciças correspondem a "um adiantamento" lançado sob a carga das populações atuais. A evolução e o desenvolvimento continuam favoráveis. Estamos ensaiando uma novidade institucional: O Estado Capitalista e Capitalizador, e formador de uma forte classe consumidora com relativa liberdade de iniciativas, de idéias e de pensamentos. Evidentemente existe um descompasso no aspecto conjuntural, sendo cedo para um julgamento definitivo. Nesta história precisávamos de verdade de uma autêntica elite dirigente ou, pelo menos, um prupo governante qualificado. A compatibilidade está lançada como uma interrogação. Resta tecermos considerações referentes ao problema da eficácia. 


\section{Autenticidade das doutrinas econômicas}

O povo, habituado durante muitos anos a uma restrição de consumo, que caracterizava um baixo nivel de vida, repentinamente atira-se a uma exuberância de tudo consumir, forçando os orçamentos oficiais pela politica de clientela, especulando de todos os modos e em tôdas as direções, não tendo qualquer preocupação de previdência ou de segurança. Concorre a compra de tudo sem se preocupar com os preços. Naturalmente, as elites têm a obrigação de levar o povo a tomar consciência da necessidade de desenvolver e mostrar a determinação de selecionar consumo e promover poupança. Por outro lado, nenhuma Nação do mundo conseguiu desenvolver-se sem se servir da poupança de outros povos. Não existe economia introvertida. Quanto mais um pais se industrializa mais necessita diversificar suas matérias-primas e ampliar mercados consumidores. Quanto mais desenvolvido mais ou capacidade de transformar e modificar pela ciência e pela técnica os setores de dependência, ao encontrar-se em uma alternativa. As elites e os lideres têm o dever de induzir o povo a Nação, dentro da contante no desenvolvimento e na evolução da

A moral dos consciência cultural que isto determina. fiança e de decisão, provocando a consciência para lutar de conobjetivo definido. Tal posição das elites, em que pesem os assuntos pessoais de consciência e espirito de classe, pode colocá-la $\mathrm{cm}$ posição destacada quando em jôgo o interêsse coletivo e os objetivos a serem perseguidos pela nacionalidade. Esta confiança é tes para escolhere o povo dispense a liberdade a seus dirigensabilidade de opinar politicamente Tecnologia fugindo à respona ser seguido. E' importante para um govêrno do caminho certo derno, ter oportunidade de concilian govêrno, no Estado Motécnica com as imposições politicas. - problema dado que iniciamos a Em nosso caso, agiganta-se Estado Bem-Estar, a satisfaras a característica mais nítida do populares conseqüentes ou decorrentes do últim de reivindicações

Para Rostov (W. Rostov, The Process of Economic Growth) o primeiro pré-requisito indispensável é a "propensão a aceitar inovações". Desenvolvimento pressupõe mudança, transformações e risco, todos conjugados em novas combinações acêrca dos fatôres de produção. Naturalmente, as inovações mais importantes situam-se na engenhosidade ativa decorrente da capacitação cientifica e na conjunção de ciência e técnica visando a Tecnologia. No Brasil, o aproveitamento do esfôrço universal, em proporções 
maiores quanto à ciência e à técnica, que não podem constituir privilégios, determina, contudo, uma consciência perfeita de adaptação, decorrente das pesquisas, especificamente dirigidas a particularizações e características nacionais. Exalta-se aqui a moral das elites e lideres, fugindo de alienações rígidas e procurando adquirir consciência dos problemas nacionais. $O$ povo năo se atém na análise e na crítica, arriscando-se algumas vêzes a praticárla no aspecto conjuntural. Contudo, a fisionomia estrutural, ampla, verdadeira e real, que ultrapassa o raciocínio vulgar, deve possuir subsidios que levem o povo a ter confiança. Este, aprecia realmente os resultados, mas encarando os de forma objetiva, concreta, imediatista e oportunista, algumas vêzes. Mais uma vez a confiança tem que ser imposta para o "compasso de espera" necessário e imperativo do processo de evolução e de execução do Planejamento. O outro requisito importante da eficácia é a possibilidade de "apropriação dos frutos do esfôrço e do sacrifício", a que Lewis denomina de "direito à recompensa". O terceiro requisito importante é a oportunidade a todos de conseguirem interpenetração nas diversas camadas sociais, quando tal condição se apóia no esfôrço individual calcado nos principios médios dos procedimentos sociais do grupo. Ai já encontramos a im* plicação intima da Politica proporcionando a recompensa devida, selecionando a capacitação dentro de oportunidades iguais, para o que deverá "igualar desigualdades", postulado constituciona! vigente tão bem interpretado por Rui Barbosa. A eficácia é o problema dos mais dificeis da conjuntura brasileira. $\mathrm{O}$ assunto exige uma posse de consciência específica das elites no sentido de corrigir mais ràpidamente a debilidade de nossa herança tecnológica. A Península Ibérica permaneceu na fase do capitalismo mercantil e em estado de semifeudalismo, enquanto outras naçñes européias já se encontravam em plena revolução industrial. O bacharelismo, a alergia à experimentação técnica e cientifica, a ojeriza aos processos educacionais ligados à ciência positiva é herança que nos afliqe na fase mais aguda da Tecnologia já com o recurso inestimável do Planejamento. No dilema entre ciência e estética, sempre nos inclinamos pela última.

Outro ponto que nos estrangula e que necessita correção a longo prazo é a audácia social, ligada à doutrina econômica sempre seguida e desviada para responsabilidade do Estado. No intarcâmbio cultural sempre praticamos a dupla cultura, onde o povo ficava à margem dos problemas que lhe diziam respeito. Ainda se pratica no País a "economia fechada e auto-suficiente" a que alguns denominam "complexo colonial", onde nas fazendas impera o desejo de atender com os próprios recursos as necessidades mais importantes. 


\section{A consciência cultural na economia politica}

No entanto, nos encontramos em uma encruzilhada do destino. Pelos vícios acima caminhamos na direção firme do Estado Capitalista e capitalizador, além de "distribuidor de oportunidades", nem sempre, no principio da "igualdade dentro da desigualdade" e da autêntica capacitação. Com êste critério torna-se formador de uma classe média apenas consumidora. Ao mesmo tempo seguimos rumo do consumo livre e ostentatório, o mais das vêzes originário da capacidade investidora, direta ou indireta do Estado. Criamos uma mentalidade de monopólios oficiais ou semioficiais que descura o interêsse pelo custo e portanto pela Tecnologia, deixando à margem a preocupação do risco. Comumente tal monopólio ou cartel acobertado pelo Estado vem beneficiar um grupo ou uma classe em detrimento dos interêsses conjunturais do povo e estruturais da Nação. O ponto importante frente à Segurança Nacional é que esta persegue a formação de um grande Estado no futuro, atendendo a necessidades de todos, aos interêsses de um maior número e a conservação da cultura totalmente assegurada. Na economia industrial, o processo tem que ser progressivo, devendo estar esgotada em breve tempo a capacidade consumidora nacional. Ai chegará a hora de disputar a concorrência internacional. Verificaremos então o elevado custo nacional causado pela imprevidência e pelo monopólio disfarçado, conjuntamente com a parca qualificação industrial motivada pelo desinterêsse dedicado à Tecnologia. Constatamos, assim, o sacri fício das gerações presentes, sem as recompensas para com as populações futuras. Nunca, pois, necessitou tanto o País da confiança aos seus homens de elite e lideres autênticos para que tomem consciência do desenvolvimento nacional racional. Como o vicio é de estrutura, ultrapassa a compreensão do povo. $\mathrm{Na}$ ausência de elites autênticas, atira-se êle a propor soluções e a tirar conclusões, decorrentes da crosta dos fatos que emergem mascarando o núcleo da realidade, só deslindável pela análise e pela crítica.

O nacionalismo é uma pressão nacional, estrutural, ideológica e favorável. Conscientemente solicitado poderá encaminhar o sentido de "confiança" nos homens de elite desde que realmente procedam visando os interêsses da coletividade.

Para conservação do atual nivel de vida necessitamos fazer investimento no montante de $12 \%$ da Renda Nacional (Alexandre Koft). Já descemos a esta taxa, mas temos contado com mais $4 \%$ da ajuda estrangeira. A situação econômica é promissora, com fácil correção na produção industrial de $9 \%$ e a entrar em produção uma pressão de energia elétrica para atender a demanda de 4 a 5 anos. 
As Micropressões conjunturais serão corrigidas pelo processo intenso de esclarecimento acêrca de problemas nacionais, caso contrário sofreremos um período negativo mais longo até que se estabeleça o reajustamento determinado pela evolução estrutural.

\section{Alguns aspectos atuais da situação econômica}

A situação econômica é satisfatória. O que está prejudicando sensivelmente a posição econômica é a agitação psicossocial e política, via de regra, ligada a interêsses pessoais. A promoção pessoal à custa de manobras e atitudes conscientemente falsas mas acessiveis a pouca compreensão de um povo ainda incipiente de educação. A nosso ver, sob o aspecto conjuntural é a pressão mais desvantajosa que nos atinge no momento, pois que ela faz hesitar a progressão das inicativas.

Estamos em vésperas de contar com efetiva produção de grandes investimentos na indústria elétrica. O campo econômico é impar como sugestão para investimentos internacionais.

A indústria mecânica pesada está em franco desenvolvimento, fato sempre constatado na dinâmica econômica que inspira confiança. Na substituição neste setor está prevista uma economia de divisas na ordem aproximada de 739,3 milhões de dölares para os próximos dez anos. Esta expansão em volume físico tem girado em tôrno de $15 \%$ anuais. No prazo mencionado acredita-se que ela atenda a $80 \%$ da demanda.

A exportação industrial, em que pesem tôdas as deformações conjunturais assinaladas, já está alcançando quase $10 \%$ do total. E' preciso ressaltar a plena iniciativa privada em tais empreendi-
mentos.

Em um exame geral pode-se afirmar a expansão de todos os negócios e sem sinais de satisfação em seu progresso.

No setor agrícola, sobretudo na produção de espécies alimentares, a pressão tem sido violenta para aumentá-la. Contudo, de 1959 1960, conseguimos um aumento de produção e razoável aumento de produtividade-área na seguinte ordem, em alguns alimentos básicos.

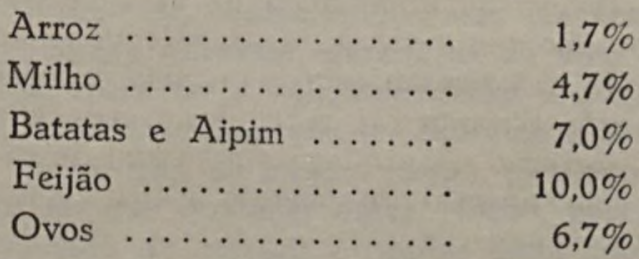


A média geral acima representa $5,85 \%$ se contrapondo com a taxa de aumento demográfico de $3,1 \%$ (ou $2,9 \%$ ?). A produção de arroz aumentou no ano seguinte tendo sido permitida a exportação. A escassez de feijão atribui-se a um desvio de financiamento para o amendoim, por solicitação de interessados. 